\title{
Biology and Distribution of Mangrove Crabs in the Wouri River Estuary, Douala, Cameroon
}

\author{
Vanessa Maxemilie Ngo-Massou ${ }^{1,2}$, Guillaume Léopold Essomè-Koum¹, \\ Ernest Kottè-Mapoko1, Ndongo Din ${ }^{1 *}$ \\ ${ }^{1}$ Department of Botany, Faculty of Science, The University of Douala, Douala, Cameroon \\ ${ }^{2}$ Department of Biological Sciences, High Teacher's Training College, The University of Yaounde I, \\ Yaounde, Cameroon \\ Email: ${ }^{\text {ndongodin@yahoo.com }}$
}

Received 12 December 2013; revised 13 January 2014; accepted 7 February 2014

Copyright (C) 2014 by authors and Scientific Research Publishing Inc.

This work is licensed under the Creative Commons Attribution International License (CC BY). http://creativecommons.org/licenses/by/4.0/

(c) (i) Open Access

\section{Abstract}

Crabs appear as the most important group of mangrove epifauna. Their distribution seems influenced by some biotic and abiotic parameters. To verify the interactions between crab populations and relevant environmental components, six mangrove sites around the city of Douala $\left(3^{\circ} 40^{\prime}\right.$ $4^{\circ} 11 ' \mathrm{~N}$ and $9^{\circ} 16^{\prime}-9^{\circ} 52$ 'E) were selected. During six months, four $25-\mathrm{min}$ independent time-biased samples methods were conducted in the plot of $4 \times 4 \mathrm{~m}^{2}$ delimited inside each zonation throughout transect. The distance from plot to water and its groundwater salinity, temperature, conductivity and $\mathrm{pH}$ were measured. The individual sex, fresh weight and carapace size were determined. 3016 individuals were harvested (57\% of females). Perisesarma kamermani was the most abundant $(29 \%)$ while Chiromates angolense was the most frequent $(13.47 \%)$. Cardisoma armatum was only found in Pandanus zone. Crab species number was positively correlated with tree, suggesting that the mangrove vegetation is important to the crab fauna as a habitat and food supply. Sex ratio showed a significant difference for Chiromates buetikoferi 1:2.34 $\left(\chi^{2}=33.21\right)$ and for Perisesarma huzardi 1.36:1 $\left(\chi^{2}=39.98\right)$. Portunus validus live closer to water between 5 - $20 \mathrm{~m}$ while Cardisoma armatum was found $70 \mathrm{~m}$ away from water. Portunus validus was present exclusively in high salinity zones whereas Perisesarma kamermani dominate in low salinity zone. This baseline ecological study of crab mangroves is important for monitoring, management and conservation of mangrove ecosystems.

\section{Keywords}

Abundance; Diversity; Frequency; Sesarmidae; Sex Ratio

\footnotetext{
${ }^{*}$ Corresponding author.
}

How to cite this paper: Ngo-Massou, V.M., et al. (2014) Biology and Distribution of Mangrove Crabs in the Wouri River Estuary, Douala, Cameroon. Journal of Water Resource and Protection, 6, 236-248. 


\section{Introduction}

Mangrove ecosystem is characterized as a forest growing in seawater at the interface between land and sea, particularly in sheltered areas with large tidal excursions. The structuring feature of mangrove forests is tree species adapted to growth in anoxic intertidal sediment saturated with seawater [1]. The diversity of these features depends on the size of the swamp which, in its turn, depends on the proximity of rivers and the tidal range. A further complication introduced by the proximity of rivers is variable salinity which may also be caused by heavy rain and poor drainage [2]. The plant species are distributed in zones or belts which are generally parallel from the coast to the external part of mangrove [3]. The vegetation structure is linked to the differences in the different species tolerance of the water's physicochemical factors (salinity, conductivity and $\mathrm{pH}$ ) throughout their gradients [4].

Worldwide, the macrobenthos are relatively poorly known compared to other aspects of these productive ecosystems, such as floristics and trophic ecology [5]-[7]. Brachyuran crabs are dominant in most mangrove habitats, high in species number, abundance and biomass compared with many other animals, thus adequate for modelling settlement in these systems [8]. They are dominated by various burrowing decapods, such as sesarmid crabs and fiddler crabs [1]. Their assemblage structure seems to be influenced by local environmental conditions. Scale-dependent patterns of distribution may be particularly important in coastal areas, since they are characterized by variability in abiotic conditions [9] [10]. The distribution of macrobenthos fauna are determined by a number of factors such as physical nature of substratum, depth, nutritive content, degree of stability and oxygen content of the water body [11].

The rate of deforestation is high in many developing countries possibly than in any others type of tropical forests [12]. Almost 53,216 ha of the Cameroon's mangrove forests have been lost over the last 13 years [13] [14]. Disturbances in mangroves have been attributed to a combination of factors such as the ever-increasing human pressure on coastal lands, sea-level rise, absence of adequate legislation regarding mangrove protection, and pollution in the peri-urban settings of the city of Douala [15] [16]. Mangrove wood products remain an important source of building materials and fuelwood for local communities [17]. They are also used as a potential source for pasture, medicine and tannins [18]. However, few data are available on the distribution of mangrove macro- benthos in Africa [19]-[23].

Most studies concern primarily their composition and abundance [11], feeding and burrowing ecology [24], mutual relationship between crabs and mangroves [25] [26], periodic vertical migrations on trees by climbing crabs [19] [27] [28], trophic roles [29], homing abilities of crabs [30], the dynamics of mangrove leaf litter, includ- ing productivity, decomposition and export [31], settlement patterns of crabs [8], effects of urban wastewater on crab and mollusc assemblages [19]. In Cameroon, recent study updates the inventory of crabs from 17 to 20 species [32].

Crabs patterns of distribution are related to salinity [33], sediment characteristics [34], temperature, ions and water availability [35], debit and $\mathrm{pH}$ [36] and topography [37]. Associated biotic factors like litters' floristic diversity, forest complexity and harvesting were identified as the determining factors which affected the distribution and abundance of mangrove crabs [38].

The faunal zonation has been recognized; however, this zonation is described only in a qualitative fashion [39] [40]. The quantitative data in mangrove environments seem difficult probably due to the complexity of the swamps involved. Following the survey carried out in this zone [32], the aim of present study is the determination of interactions between crabs and relevant environmental components in mangrove. Three hypotheses were tested in this study: 1) there is no difference in crab species richness between the previous studies and this study; 2) there is no biased sex ratio in each crab species population; 3) the distribution of crab species and density are no different between mangrove tree species belt properties.

\section{Materials and Methods}

\subsection{Study Area}

The study was carried out in the mangrove of the Wouri River estuary $\left(3^{\circ} 40^{\prime}-4^{\circ} 11^{\prime} \mathrm{N}\right.$ and $\left.9^{\circ} 16^{\prime}-9^{\circ} 52^{\prime} \mathrm{E}\right)$ (Figure 1). The climate of the region belongs to the Equatorial regime of a particular type. It is characterized by a long rainy season (March-November) and a short dry season (December-February). Heavy rainfall (approximately $4000 \mathrm{~mm}$ per year) with high and stable temperatures (annual average temperature is $26.7^{\circ} \mathrm{C}$ ) and a high 


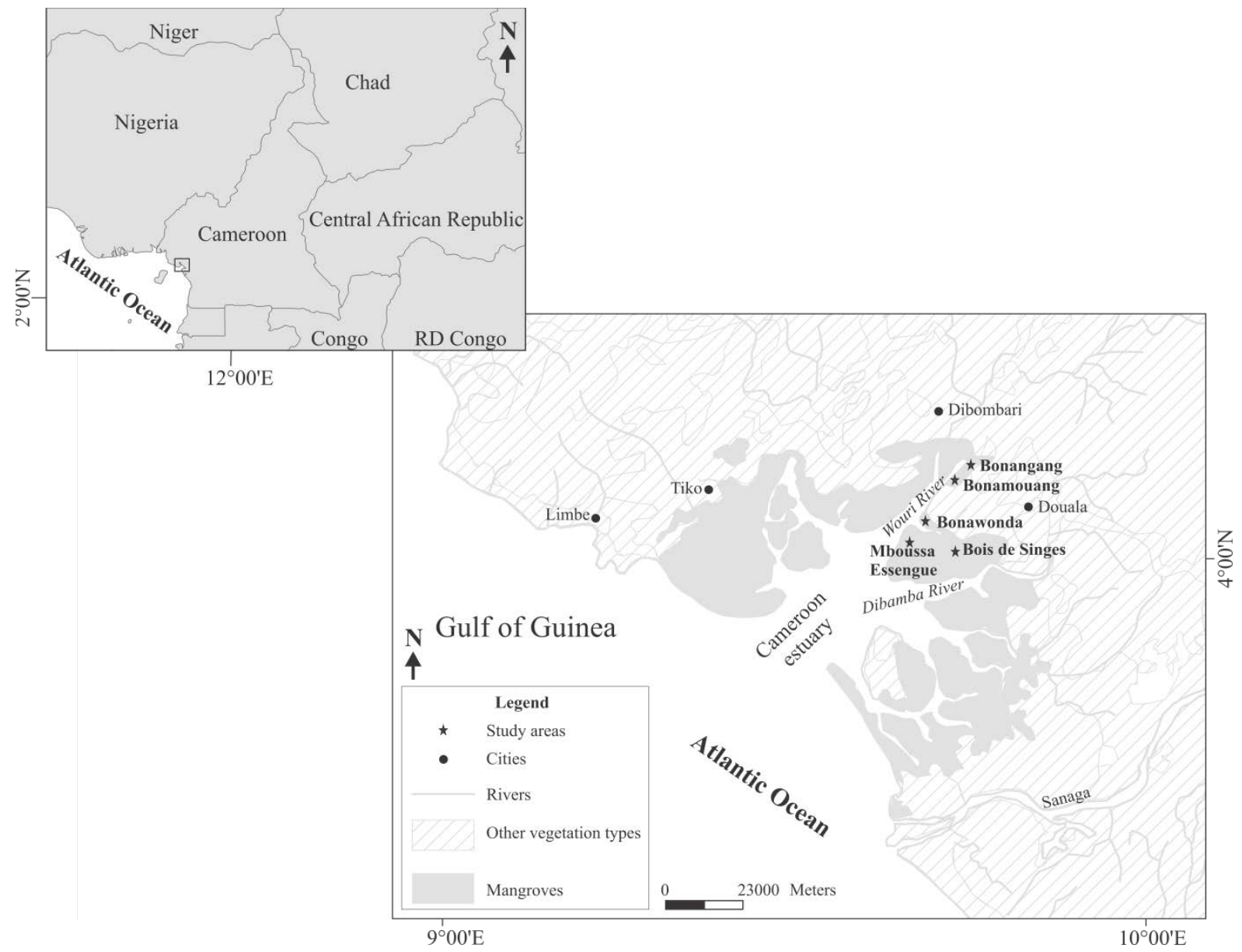

Figure 1. Location of the study areas (modified from [32]).

humidity throughout the year approaching 100\%, are typical for this region. Monsoon watering the region has a low wind gust with the exception of its phases of onset (April-May) and withdrawal (September-October), accompanied by relative violent storms.

The tide rhythm is semi-diurnal with average amplitude of $2.5 \mathrm{~m}$. Soils are grey or black muds, of silty texture, sand or clay, formed from fluvial sediments relatively rich in organic matter. These are young clay soils, characterized by a high carbon/nitrogen $(\mathrm{C} / \mathrm{N})$ ratio due to the slowdown in biological activity as a result of anoxia conditions. The annual variation in salinity in the region is between 0 and $20 \%$. During the long rainy season, the salinity of waters draining twice the mangrove is always $<10 \%$. During the dry season, salinity varies between 4 and 20\%. Less than $30 \mathrm{~km}$ away from the ocean, salinity in Douala mangroves is zero during the rainy season [4].

The flora consists essentially of tree species. The herbaceous stratum represents $<1 \%$ of all vegetation. However, the flora remains poor with Rhizophora racemosa GF Meyer being largely the dominant vegetation. The fauna includes vertebrates such as birds, reptiles and fish, but especially a wide range of invertebrates, mainly crabs and molluscs, which constitute the bulk of submerged and epibenthic wildlife in the region.

\subsection{Sampling Design}

Six study sites were selected on each side of the Wouri River bridge based on their accessibility, their floristic composition and their crab species characteristics. A detailed description of the macrobenthos assemblages of study area is contained in [32]. At each site, one transect was opened perpendicularly to the main channel, from water to land varied from 70 to $100 \mathrm{~m}$ according to the floristic diversity. Crabs were collected at the day, during six months in the rainy season, at the low neap tide and then repeated at the low spring tide. A plot of $4 \times 4 \mathrm{~m}^{2}$ 
was delimited into each tree species characteristic belt [41]. Thirty-nine (39) plots were sampled covering an area of $624 \mathrm{~m}^{2}$. Six plots corresponding to six tree species belt were sampled in Site 1, seven plots in Site 2, five in Site 3, nine in Site 4, eight in Site 5 and four in Site 6.

There are several techniques for sampling mangrove crabs, but unbiased sampling is difficult without employing highly intrusive and labour intensive methods. Four 25-min independent time-biased samples were conducted in each plot [42]. One sample (= one replicate) represents approximately one half of the $16 \mathrm{~m}^{2}$ plot for one person collecting crabs for $25 \mathrm{~min}$. Crabs were counted and caught by hands on the trees, dead wood and detritus on the plot surface. Leaves of young plants were deposited on the ground to incite crabs to come out from their burrows. All burrow excavation at $10-20 \mathrm{~cm}$ deep was used for more active and conspicuous species. The crabs were sedated in iced water for a few minutes, washed and stored in $70 \%$ alcohol. The number of green (freshly fallen), yellow (senescent) and brown (decaying) leaves was counted at the time of sampling in the plots.

\subsection{Measurement of Parameters}

For any crab caught, individual sex, fresh weight and carapace size (carapace length (CL) and carapace width (CW)) were measured in the laboratory. Distance of each plot to water was measured and first plot was fixed at $5 \mathrm{~m}$ from water because of substrate instability. Distances have been ranged into seven classes $(5-20 \mathrm{~m}, 20$ - 30 m, 30 - 40 m, 40 - 50, 50 - 60 m, 60 - $70 \mathrm{~m}$ and 70 and plus). At low tide, a $20 \mathrm{~cm}$ deep hole has been dug into the ground. Four physicochemical parameters (conductivity, temperature, salinity and $\mathrm{pH}$ ) were measured in situ from this groundwater using portable field equipment (WTW: Standard Conductivity Cell, TetraCon $325 \mathrm{and} \mathrm{pH}$ Meter 330/7/SET).

\subsection{Data Analysis}

The following ecological parameters were assessed to describe the structure and composition of crabs (absolute density: number of individuals $/ \mathrm{m}^{2}$; relative density: number of individuals per species/total number of individuals; species occurrence; specific diversity has been expressed in Shannon-Weaver index (H') and Pielou's evenness (J) or equitability index). We have also determined a probability to encounter an individual in each site which is the sum of species occurrence divided by the total number of possible observations, where every species is considered as a data series.

The sex ratio was given as males/females (M/F) calculated using the formula: total number of males/total number of females [43]. To analyze global data of communities' structure, STATISTICA Software was used. The chi-square test $\left(\chi^{2}\right)$ and One-Way analysis of variance (ANOVA) were used to verify the significant differences between the sex ratio of species and commonly expected 1:1 sex ratio [44]. When significant variations are detected with ANOVA, Turkey's test was performed to determine the locations of significant differences. The relationship between salinity and conductivity was established and evaluated using Pearson's correlation. The Mann-Whitney (U) test was also used to observe differences between transects and time of collection (at spring or neap tides). Spearman's Rank Correlation Test was used to determine the relationship between environmental parameters and biotic variables (abundance, diversity and species richness).

\section{Results}

\subsection{Population Structure}

The composition, abundance and distribution of crabs within the sites are shown in Table 1. In total, 3016 individuals were captured, 1679 in the neap and 1337 during the spring samplings. Individuals were grouped into 12 species, nine genera and five families. Perisesarma kamermani (De Man 1883) was the most abundant (29\%) while Cardisoma armatum (Herklots 1851$)$ was the least abundant $(0.23 \%)$. The high density was obtained by $P$. kamermani (1.4 individuals $\left.\mathrm{m}^{-2}\right)$ and the low by C. armatum (0.01 individual $\left./ \mathrm{m}^{2}\right)$. According to the Shannon-Weaver index $\left(\mathrm{H}^{\prime}\right)$, Site 4 was the most diversified (0.53). Evenness index $(\mathrm{J})$ shown that individuals in site 3 (0.06) were better distributed (Table 2). There were no significant differences of the crab measures between replicates and the time of collection (spring or neap tides) in each plot, although there were significant differences in the transects in terms of abundance and species number among transects (Mann-Whitney $\mathrm{U}=92$ and 73 respectively, $\mathrm{n}=6, \mathrm{p}<0.005$ ). 
Table 1. Composition of crabs in the Wouri river Mangrove. $n$, number of individuals per species; N, total number of individuals per site; c, species occurrence; D, relative density; Freq., Frequency; p, probability to encounter an individual in each site. Thirty-nine (39) plots were sampled covering an area of $624 \mathrm{~m}^{2}$. Site 1, Bois de Singes (5 plots); Site 2, Bonangang (7 plots); Site 3, Bonamouang (3 plots); Site 4, Bon’Ewonda (13 plots); Site 5, Mboussa Essengue (8 plots) and Site 6 , Wouri River bridge (3 plots).

\begin{tabular}{|c|c|c|c|c|c|c|c|c|c|c|c|c|c|c|c|}
\hline \multirow{2}{*}{ SPECIES } & \multicolumn{2}{|c|}{ Site 1} & \multicolumn{2}{|c|}{ Site 2} & \multicolumn{2}{|c|}{ Site 3} & \multicolumn{2}{|c|}{ Site 4} & \multicolumn{2}{|c|}{ Site 5} & \multicolumn{2}{|c|}{ Site 6} & \multirow{2}{*}{ Total } & \multirow{2}{*}{ D } & \multirow{2}{*}{ Freq. } \\
\hline & $\mathbf{n}$ & c & $\mathbf{n}$ & c & $\mathbf{n}$ & c & $\mathbf{n}$ & c & $\mathbf{n}$ & c & n & c & & & \\
\hline Armase elegans & 0 & 0 & 62 & 4 & 0 & 0 & 38 & 3 & 122 & 6 & 24 & 2 & 246 & 8.16 & 7.77 \\
\hline Cardisoma armatum & 0 & 0 & 0 & 0 & 0 & 0 & 7 & 2 & 0 & 0 & 0 & 0 & 7 & 0.23 & 1.04 \\
\hline Chiromantes angolense & 12 & 2 & 66 & 7 & 11 & 2 & 62 & 6 & 127 & 7 & 29 & 2 & 307 & 10.18 & 13.47 \\
\hline Chiromantes buetikoferi & 0 & 0 & 64 & 5 & 36 & 2 & 187 & 9 & 79 & 6 & 96 & 3 & 462 & 15.32 & 12.95 \\
\hline Metagrapsus curvatus & 40 & 4 & 51 & 4 & 12 & 3 & 93 & 5 & 167 & 8 & 0 & 0 & 363 & 12.04 & 12.43 \\
\hline Pachygrapsus transversus & 28 & 3 & 0 & 0 & 0 & 0 & 235 & 8 & 54 & 4 & 78 & 3 & 395 & 13.10 & 9.32 \\
\hline Perisesarma alberti & 15 & 4 & 29 & 6 & 13 & 3 & 71 & 5 & 25 & 7 & 0 & 0 & 153 & 5.07 & 12.95 \\
\hline Perisesarma huzardi & 7 & 1 & 49 & 7 & 6 & 0 & 15 & 5 & 0 & 0 & 0 & 0 & 77 & 2.55 & 7.77 \\
\hline Perisesarma kamermani & 131 & 4 & 0 & 0 & 0 & 0 & 247 & 8 & 383 & 8 & 115 & 3 & 876 & 29.05 & 11.91 \\
\hline Portunus validus & 12 & 3 & 13 & 3 & 0 & 0 & 0 & 0 & 0 & 0 & 0 & 0 & 25 & 0.83 & 3.11 \\
\hline Sesarma sp. & 0 & 0 & 35 & 4 & 0 & 0 & 28 & 4 & 8 & 1 & 0 & 0 & 71 & 2.35 & 4.66 \\
\hline Uca tangeri & 0 & 0 & 0 & 0 & 13 & 3 & 12 & 1 & 0 & 0 & 9 & 1 & 34 & 1.13 & 2.59 \\
\hline $\mathbf{N} / \mathbf{p}$ & 245 & 0.35 & 369 & 0.48 & 91 & 0.36 & 995 & 0.36 & 965 & 0.49 & 351 & 0.39 & 3016 & 100.00 & 100.00 \\
\hline
\end{tabular}

Table 2. Diversity of crabs in the sampling sites.

\begin{tabular}{|c|c|c|c|c|c|c|}
\hline \multirow{2}{*}{ Parameters } & \multicolumn{6}{|c|}{ SITES } \\
\hline & 1 & 2 & 3 & 4 & 5 & 6 \\
\hline Area $\left(m^{2}\right)$ & 80 & 112 & 48 & 208 & 128 & 48 \\
\hline Number of individuals (N) & 245 & 369 & 91 & 995 & 965 & 351 \\
\hline Number of species (S) & 7 & 8 & 6 & 11 & 8 & 6 \\
\hline Absolute density (individuals $/ \mathrm{m}^{2}$ ) & 3.06 & 3.29 & 1.89 & 4.78 & 7.54 & 7.31 \\
\hline Shannon-Weaver index (H') & 0.29 & 0.37 & 0.15 & 0.53 & 0.52 & 0,36 \\
\hline Evenness index (J) & 0.10 & 0.12 & 0.06 & 0.15 & 0.17 & 0.14 \\
\hline
\end{tabular}

\subsection{Biological Characteristics}

Females were more numerous (57\% of individuals). Significant differences were observed in terms of sex ratio for two species. Chiromates buetikoferi (De Man 1883) sex ratio was 1:2.34 $\left(\chi^{2}=33.21\right.$ ), showing a predominance of females and Perisesarma huzardi (Desmarest 1925) sex ratio was 1.36:1 $\left(\chi^{2}=39.98\right)$, showing a predominance of males.

Detailed biological parameters of crab species is contained in Table 3 . The high mean value of carapace size was recorded for $C$. armatum with $13.13 \pm 4.49 \mathrm{~cm}$ for width and $9.79 \pm 3.60 \mathrm{~cm}$ for length. The low mean was obtained for Armase elegans (Herklots 1851) with $2.05 \pm 0.55$ for width and $2.03 \pm 0.26 \mathrm{~cm}$ for length. The mean fresh weight was $136.6 \pm 52.8 \mathrm{~g}$ for C. armatum and $7.93 \pm 1.44 \mathrm{~g}$ for A. elegans.

According to sex distribution, male carapace width ranged from $1.5 \mathrm{~cm}$ to $15.7 \mathrm{~cm}$, the carapace length varies from 0.9 to $13.0 \mathrm{~cm}$ and weight varies from 5.6 to $158.9 \mathrm{~g}$. For females, the carapace width ranged from $1.4 \mathrm{~cm}$ to $15.2 \mathrm{~cm}$, the carapace length varies from 0.8 to $11.3 \mathrm{~cm}$ and fresh weight varies from 5.2 to $155 \mathrm{~g}$.

The size frequency distribution differed from normality for the most species. They were better described by a bimodal distribution. There was a significant difference between carapace width of males and females $\left(\chi^{2}=\right.$ 279077.3, df $=3014, \mathrm{p}<0.001)$. The same observations have been shown for carapace length of males and females $\left(\chi^{2}=283605.6, \mathrm{df}=3014, \mathrm{p}<0.001\right)$ and for weight of males and females $\left(\chi^{2}=236133.0, \mathrm{dl}=3015, \mathrm{p}<\right.$ $0.001)$. Individual weight and carapace width showed a significant positive correlation and the regression equation generated is of the type $y=13.59 x-32.33\left(r^{2}=0.58, p<0.005\right)$. Carapace length and carapace width are highly correlated $\left(r_{s}=0.79, p<0.001\right)$, likewise fresh weight and carapace length $\left(r_{s}=0.65, p<0.001\right)$ and 
Table 3. Biological parameters of crab’s species M: males, F: females, n: abundance, Min: minimum, Max: maximum, SD: standard deviation, similar case alphabets indicate a significant difference (Turkey’s test; $\mathrm{p}<0.05$ ).

\begin{tabular}{|c|c|c|c|c|c|c|c|c|c|c|c|c|}
\hline \multirow[b]{2}{*}{ Species } & \multirow[b]{2}{*}{ Sex } & \multirow[b]{2}{*}{$\mathbf{n}$} & \multirow[b]{2}{*}{$\begin{array}{l}\text { Sex } \\
\text { ratio }\end{array}$} & \multicolumn{3}{|c|}{ Width (cm) } & \multicolumn{3}{|c|}{ Length (cm) } & \multicolumn{3}{|c|}{ Weight (g) } \\
\hline & & & & Mean \pm SD & Mean & Min-Max & Mean \pm SD & mean & Min-Max & Mean \pm SD & mean & Min-Max \\
\hline \multirow{2}{*}{$\begin{array}{l}\text { Armase } \\
\text { elegans }\end{array}$} & M & 94 & \multirow{2}{*}{$1: 1.6$} & \multirow{2}{*}{$2.05 \pm 0.55^{b}$} & & & \multirow{2}{*}{$2.03 \pm 0.26^{\mathrm{b}}$} & & & \multirow{2}{*}{$7.93 \pm 1.44^{\mathrm{a}}$} & 9.46 & $7.9-10.6$ \\
\hline & $\mathrm{F}$ & 152 & & & $2.16 \pm 4.7$ & $1.7-2.9$ & & $1.96 \pm 5.6$ & $1.4-2.5$ & & $6.99 \pm 5.7$ & $5.2-9.2$ \\
\hline \multirow{2}{*}{$\begin{array}{c}\text { Cardisoma } \\
\text { armatum }\end{array}$} & M & 3 & \multirow{2}{*}{$1: 1.3$} & \multirow{2}{*}{$13.13 \pm 4.49^{j}$} & $15.03 \pm 3.7$ & $14-15.7$ & \multirow{2}{*}{$9.79 \pm 3.60^{j}$} & j $11.4 \pm 6.6$ & & \multirow{2}{*}{$136.6 \pm 52.8^{h}$} & $157.13 \pm 3.2$ & $156.3-$ \\
\hline & $\mathrm{F}$ & 4 & & & $14.45 \pm 3.0$ & 13.6-15.2 & & $10.7 \pm 6.2$ & $9.1-11.3$ & & $153.8 \pm 2.09$ & 152.2 - 155 \\
\hline \multirow{2}{*}{$\begin{array}{c}\text { Chiromantes } \\
\text { angolense }\end{array}$} & $\mathrm{M}$ & 127 & \multirow{2}{*}{$1: 1.4$} & \multirow{2}{*}{$3.48 \pm 0.23^{\mathrm{c}}$} & $3.48 \pm 2.6$ & 2.9-3.9 & \multirow{2}{*}{$2.97 \pm 0.22^{d}$} & $2.97 \pm 7.4$ & $2.5-4.3$ & \multirow{2}{*}{$9.18 \pm 0.19^{b}$} & $9.18 \pm 3.3$ & $8.8-9.7$ \\
\hline & $\mathrm{F}$ & 180 & & & $3.49 \pm 3.01$ & $2.8-4.1$ & & $2.87 \pm 7.02$ & $22.4-3.9$ & & $9.18 \pm 3.6$ & $8.6-10.2$ \\
\hline \multirow{2}{*}{$\begin{array}{c}\text { Chiromantes } \\
\text { buetikoferi }\end{array}$} & $\mathrm{M}$ & 122 & \multirow{2}{*}{$1: 2.3$} & \multirow{2}{*}{$2.35 \pm 0.75^{\mathrm{a}}$} & $2.44 \pm 2.9$ & $1.7-4.7$ & \multirow{2}{*}{$1.51 \pm 0.61^{\mathrm{a}}$} & $1.59 \pm 9.4$ & $0.9-3.4$ & \multirow{2}{*}{$7.16 \pm 3.39^{\mathrm{a}}$} & $7.59 \pm 4.01$ & $5.6-17$ \\
\hline & $\mathrm{F}$ & 286 & & & $2.31 \pm 3.01$ & $1.7-4.7$ & & $1.47 \pm 4.6$ & $0.8-3.2$ & & $6.95 \pm 3.04$ & 5.2 - 16.6 \\
\hline \multirow{2}{*}{$\begin{array}{c}\text { Metagrapsus } \\
\text { curvatus }\end{array}$} & $\mathrm{M}$ & 175 & \multirow{2}{*}{$1: 1.3$} & \multirow{2}{*}{$4.23 \pm 0.30^{\mathrm{e}}$} & $4.23 \pm 4.2$ & $1.5-4.7$ & & $3.23 \pm 3.5$ & $2.9-3.4$ & & $16.42 \pm 5.7$ & $14.7-20.6$ \\
\hline & $\mathrm{F}$ & 242 & & & $4.24 \pm 5.4$ & $1.4-4.9$ & & $3.13 \pm 3.1$ & $2.9-3.7$ & & $16.44 \pm 4.9$ & $15.9-18.2$ \\
\hline Pachygrapsus & $s \mathrm{M}$ & 35 & & & $8.68 \pm 4.9$ & $8.2-9.3$ & & $8.18 \pm 2.9$ & $7.9-9.1$ & & $21.46 \pm 2.8$ & $20.9-22$ \\
\hline transversus & $\mathrm{F}$ & 42 & & & $8.62 \pm 2.2$ & 8.1-8.9 & & $8.15 \pm 2.3$ & $7.8-8.7$ & & $21.45 \pm 2.5$ & $20.6-23$ \\
\hline Perisesarma & $\mathrm{M}$ & 350 & $1 \cdot 1$ & 39 & $6.9 \pm 2.3$ & $6.6-7.3$ & $19^{g}$ & $6.14 \pm 4.8$ & $5.7-6.6$ & e & $17.39 \pm 13.6$ & $16.2-18$ \\
\hline alberti & $\mathrm{F}$ & 526 & & & $6.91 \pm 2.2$ & $6.6-7.5$ & & $6.04 \pm 3.9$ & $5.7-6.4$ & & $17.42 \pm 12.3$ & $17-18.4$ \\
\hline Perisesarma & $\mathrm{M}$ & 228 & $1.4: 1$ & $3.81 \pm 0.22^{\mathrm{d}}$ & $3.8 \pm 7.1$ & $3.5-5.1$ & $3.11 \pm$ & $3.1 \pm 2.6$ & $2.8-4.5$ & $8.23+0.32^{\mathrm{a}, \mathrm{b}}$ & $8.2 \pm 4.2$ & $7.3-8.6$ \\
\hline huzardi & $\mathrm{F}$ & 167 & & & $3.8 \pm 5.08$ & 4.8-6.9 & $0.21^{\mathrm{d}, \mathrm{e}}$ & $3.1 \pm 2.2$ & $2.9-5.3$ & $8.23 \pm 0.32$ & $8.2 \pm 4.5$ & $8-9.2$ \\
\hline Perisesarma & $\mathrm{M}$ & 92 & $1.5: 1$ & $4.81 \pm 0.21^{\mathrm{f}}$ & $4.71 \pm 7.07$ & 6.7-9.2 & $3.90 \pm 0.36^{f}$ & f $6.14 \pm 5.3$ & $6.1-8.4$ & $10.92 \pm 0.58^{\mathrm{d}}$ & $17.39 \pm 5.3$ & $16.2-25.4$ \\
\hline kamermani & $\mathrm{F}$ & 61 & & & $4.81 \pm 7.09$ & $5.9-7.5$ & & $6.04 \pm 3.7$ & $5.9-7.8$ & 10.32 & $17.42 \pm 6.4$ & $14.6-23.4$ \\
\hline Portunus & M & 17 & & & $10.64 \pm 4.4$ & $9.1-12.3$ & & i $8.71 \pm 4.4$ & $8.3-9.1$ & & $51.12 \pm 1.7$ & $50.4-52.5$ \\
\hline validus & $F$ & 8 & & & $10.84 \pm 4.1$ & $10.4-11.7$ & & $8.7 \pm 4.9$ & $8.2-9$ & & $51.13 \pm 1.2$ & $50.6-53$ \\
\hline Sesc & M & 38 & $1.2: 1$ & $2.61 \pm 0.75^{\mathrm{b}}$ & $2.25 \pm 2.7$ & $1.8-3$ & $2.24 \pm 0.74^{\mathrm{C}}$ & с $1.88 \pm 3.4$ & $1.5-2.3$ & $10.5 \pm 01.14^{\mathrm{c}, \mathrm{d}}$ & d $11.03 \pm 4.02$ & 10.7 - 11.4 \\
\hline & $\mathrm{F}$ & 33 & & & $2.29 \pm 2.5$ & $1.6-2.4$ & & $1.92 \pm 3.7$ & $1.5-2.7$ & & $11.07 \pm 3.7$ & 10.6 - 12 \\
\hline Uca tangeri & M & 17 & $1: 1$ & $4.05 \pm 0.35^{\mathrm{d}, \mathrm{e}}$ & $4.03 \pm 5.6$ & $3.5-4.9$ & $3.72 \pm 0.39^{f}$ & f $3.65 \pm 2.6$ & $3.1-4.6$ & $8.26 \pm 0.28^{\mathrm{a}, \mathrm{b}, \mathrm{c}}$ & $8.22 \pm 5.2$ & $7.8-10$ \\
\hline & $\mathrm{F}$ & 17 & & & $4.05 \pm 4.9$ & $3.5-5.1$ & & $3.72 \pm 2.1$ & $3.1-4.5$ & & $8.26 \pm 5.03$ & $7.3-9$ \\
\hline
\end{tabular}

carapace width of males and females $\left(\mathrm{r}_{\mathrm{s}}=0.86, \mathrm{p}<0.001\right)$.

\subsection{Spatial Distribution of Individuals}

The environmental parameters recorded in this study are summarized in Table 4. Salinity of groundwater varies considerably from water to land. During the rainy season, salinity ranged from 2.4 to $9 \mathrm{~g} \cdot \mathrm{l}^{-1}$ at low tide. Conductivity varies from 8.7 to $15.8 \mathrm{mS} \cdot \mathrm{cm}^{-1}$ and temperature from $26.1^{\circ} \mathrm{C}$ to $29^{\circ} \mathrm{C}$. $\mathrm{pH}$ was slightly acid and varied from 6.12 to 6.41 . The hygrometry level remains high and varied from $73.3 \%$ to $80.6 \%$. Spearman correlation coefficient shows that conductivity and salinity are always highly correlated $\left(\mathrm{r}_{\mathrm{s}}=0.994, \mathrm{n}=9\right.$, $\left.\mathrm{p}<0.01\right)$ in different vegetation stands.

Portunus validus (Herklots 1851) exclusively prefers zones with relatively high salinity ( $\geq 8 \mathrm{~g} / \mathrm{l})$ while $P$. kamermani dominates in zones with low salinity ( $\leq 2.4 \mathrm{~g} / \mathrm{l})$. Uca tangeri (Eydoux 1835) was only present in zones of high temperature $\left(29^{\circ} \mathrm{C}\right)$ while $P$. huzardi dominates in zones of low temperature $\left(<26.5^{\circ} \mathrm{C}\right)$. Salinity was positively and significantly correlated with crab species number and density $\left(\mathrm{r}_{\mathrm{s}}=0.057, \mathrm{n}=9, \mathrm{p}<0.01\right.$ and $\mathrm{r}_{\mathrm{s}}=$ 0.032, $\mathrm{n}=9$, $\mathrm{p}<0.01)$. Temperature and $\mathrm{pH}$ are negatively and significantly correlated with crab species richness $\left(r_{s}=-0.77, n=9, p<0.5\right.$ and $\left.r_{s}=0.72 ; n=9, p<0.5\right)$ and density $\left(r_{s}=-0.85, n=9, p<0.5\right.$ and $r_{s}=-0.81$, $\mathrm{n}=9$, $\mathrm{p}<0.5$, Table 5).

The zone of Rhizophora spp. was the most diversified (eight species of crabs) and abundant (26.52\%). The zone of Laguncularia racemosa (L.) Gaertn. f. had only three species and least abundant (2.32\%). Chiromates angolense (Brito Capello 1864) was the most frequent (13.47\%), it was found on eight zones with the exception the zone of L. racemosa. C. armatum was only found in the zone of P. candelabrum. There was a high significant difference of crab density $(\mathrm{r}=0.038, \mathrm{p}<0.001)$ between the zones of L. racemosa and Nypa 
Table 4. Physicochemical characteristics of soil water under vegetation.

\begin{tabular}{lcccc}
\hline \multirow{2}{*}{\multicolumn{1}{c}{ Vegetation }} & \multicolumn{3}{c}{ Ground water physicochemical conditions } \\
\cline { 2 - 5 } & Temperature $\left({ }^{\circ} \mathbf{C}\right)$ & $\mathbf{p H}$ & Conductivity (mS/cm) & Salinity (g/l) \\
\hline Avicennia germinans (L.) Stearn & $27.5 \pm 0.7$ & $6.33 \pm 0.8$ & $15.8 \pm 2.6$ & $9 \pm 1.7$ \\
Cynometra mannii Oliv. & $26.1 \pm 0.4$ & $6.35 \pm 0.9$ & $14 \pm 1.8$ & $8.5 \pm 1.5$ \\
Guibourtia demeusei (Harms) & $27.3 \pm 0.6$ & $6.37 \pm 0.87$ & $13.3 \pm 1.4$ & $7.4 \pm 1.1$ \\
Hibiscus tiliaceus L. & $28.8 \pm 0.8$ & $6.36 \pm 0.86$ & $11.5 \pm 1.1$ & $6.7 \pm 1.0$ \\
Laguncularia racemosa (L.) Gaertn. f. & $27.2 \pm 0.5$ & $6.12 \pm 0.7$ & $12.2 \pm 1.2$ & $8.1 \pm 1.2$ \\
Pandanus candelabrum P. Beauv. & $27.5 \pm 0.76$ & $6.21 \pm 0.78$ & $10.9 \pm 1.0$ & $7.2 \pm 1.0$ \\
Nypa fruticans Thurnb. Wurmb. & $29 \pm 1.1$ & $6.26 \pm 0.8$ & $13.6 \pm 1.6$ & $6.9 \pm 1.1$ \\
Raphia palma-pinus Gaertn. & $28.6 \pm 1.0$ & $6.37 \pm 0.89$ & $8.7 \pm 0.9$ & $2.4 \pm 0.3$ \\
Rhizophora spp. & $27.8 \pm 0.8$ & $6.41 \pm 1.0$ & $12.4 \pm 1.3$ & $7.5 \pm 1.2$ \\
\hline
\end{tabular}

Table 5. Spearman's correlations between biotic and environmental parameters.

\begin{tabular}{lcccc}
\hline & Temperature $\left({ }^{\circ} \mathbf{C}\right)$ & pH & Conductivity (mS/cm) & Salinity (g/l) \\
\hline Diversity & $+* *$ & $+* *$ & $+* * *$ & $+\mathrm{ns}$ \\
Species rich & $-* *$ & $-\mathrm{ns}$ & $+* * *$ & $+\mathrm{ns}$ \\
Density & $-\mathrm{ns}$ & $-* *$ & $+* *$ & $+*$ \\
\hline
\end{tabular}

+: positive correlation; -: negative correlation; ns: no significant correlation ( $>>0.01 / 0.05)$; ***: significant correlation (p < 0.01); **: significant correlation $(p<0.05)$.

fruticans Thurnb. Wurmb. (Figure 2). A. elegans (23\%) and P. huzardi (27.6\%) were more abundant in Guibourtia demeusei (Harms) and Cynometra mannii Oliv. were associated to the zone vegetation. Pachygrapsus transversus (Gibbes 1850) with $72.85 \%$ and C. buetikoferi (35\%) dominate in the zone with L. racemosa and Hibiscus tiliaceus L. respectively.

The crab distribution patterns have shown two major trends with respect to water proximity. Some crab species were found in many distance classes, but others were only encountered in specific interval. The first group was divided into three categories: 1) population decreased from water to land (P. transversus and P. kamermani), 2) population increased in that direction (A. elegans, Metagrapsus curvatus (H. Milne Edwards, 1837) and Perisesarma alberti), and 3) population evolved randomly ( $P$. huzardi). In the second group, C. armatum was found only about $70 \mathrm{~m}$ from water, $U$. tangeri between 50 - $60 \mathrm{~m}$ while $P$. validus live closer to water (5 - $20 \mathrm{~m}$ ). $P$. kamermani dominates in all established classes. The highest abundance (20.12\%) and the most number of species (nine species) have been obtained in class 50 - $60 \mathrm{~m}$.

\section{Discussion}

\subsection{Species Characteristics}

The same crab species were collected and their densities are higher in spite of small sample area covered in this study. These high crab densities could be that, the period of crab collection has coincided with the maximum rupture periods corresponding to the rainy season. Females were over-represented in more than $66 \%$ of the species. All species have presented a sex ratio biased with exception for $U$. tangeri. The observed sex ratio of $U$. tangeri (1:1) is very surprising, because most Uca species (U. annulipes (H. Milne Edwards, 1852) and $U$. beebei (Crane, 1941)) have shown biased sex ratios in Mozambique and Panama mangrove areas [45] [46].

Male-biased sex ratio patterns as found for four species: P. huzardi, P. kamermani, P. validus and Sesarma sp., but $P$. validus has already presented a biased sex ratio in the previous study in another part of the Cameroon Estuary mangroves by [47]. Generally only fiddler crabs exhibit adult sex ratios biased in favor of males in at least 14 species which can be explained by differential growth rates, differential production of gametes and differential mortality between the sexes [48]. On the literature, there are few data on sex ratio concerning others species encountered in this study. According to [49], the lunar phases and intertidal zonation are related to sex ratio variation in brachyuran crabs.

The values of carapace width and bimodal distribution of Uca tangeri indicate a juvenile and good recruitment. The similar frequency distribution had obtained for $U$. tangeri in Brazil [50] and Mozambique mangrove 


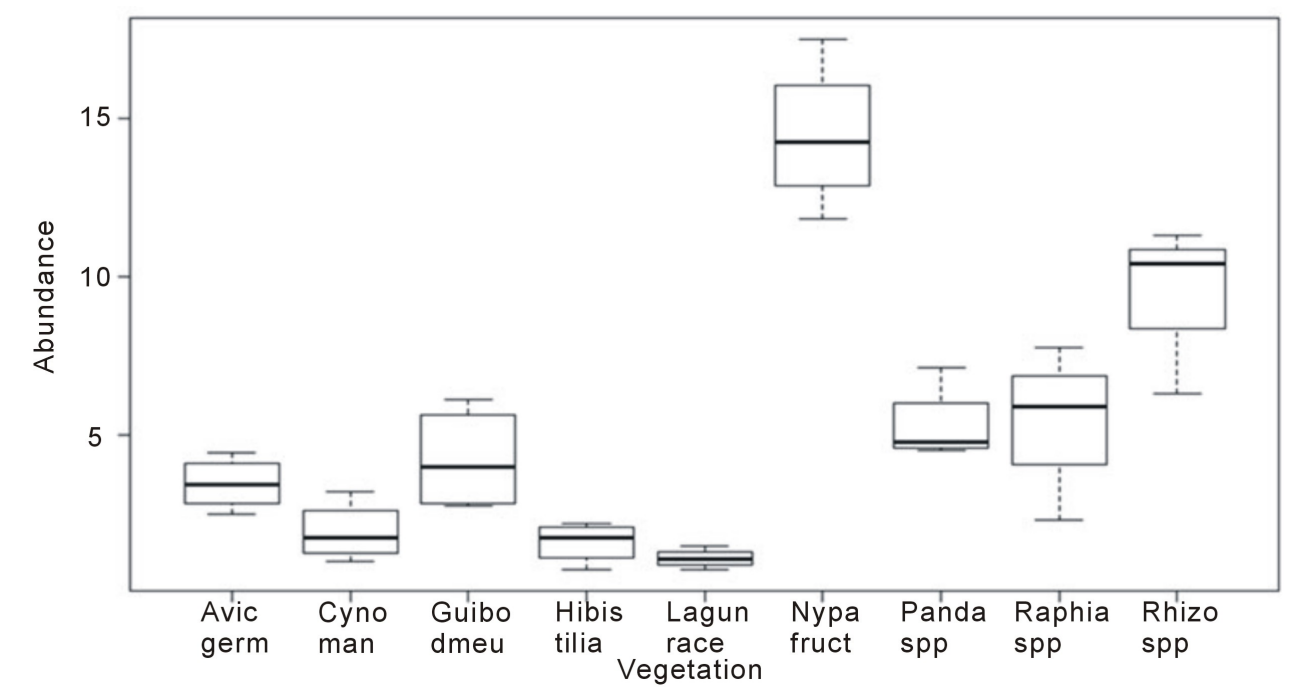

Figure 2. Abundance of crabs based on vegetation of Wouri River mangove. Box plot shows a high significant difference between Laguncularia racemosa and Nypa fruticans densities ( $\mathrm{r}=0.038$; $\mathrm{p}<$ 0.001). Avic germ, Avicennia germinans; Cyno man, Cynometra mannii; Guibo demeu, Guibourtia demeusei; Hibis tilia, Hibiscus tiliaceus; Lagun race, Laguncularia racemosa; Nypa fruct, Nypa fruticans; Panda spp., Pandanus candelabrum; Raphia spp., Raphia palma-pinus; Rhizo spp., Rhizophora spp.

areas [51]. The values of carapace width found for A. elegans $(2.05 \pm 0.55 \mathrm{~cm})$, C. buetikoferi $(2.35 \pm 0.75 \mathrm{~cm})$ and Sesarma sp. $(2.61 \pm 0.75 \mathrm{~cm})$ are very close with that obtained for some Sesarma species in other studies [47] [52]. Contrariwise, U. tangeri $(4.05 \pm 0.35 \mathrm{~cm})$ encountered are very big than $U$. rapax (Smith, 1870), U. morax (Smith, 1870) and U. pugilor (Bosc, 1802) [48] [53] [54]. U. tangeri, the only African Uca species is well known that this is the biggest species of genus Uca [55].

\subsection{Distribution of Crab Parameters}

\subsubsection{Influence of Vegetation}

The importance of vegetation in distribution of macro-fauna has been widely studied [56] [57]. Floristic diversity and crabs diversity in the area are highly correlated $\left(r_{s}=0.26, n=9, p<0.005\right)$. The vegetation is highly dominated by Rhizophora and that zone is regularly undergone tidal alternation and deposition of sediments and nutrients with relatively high salinity. Mangrove crabs are marine-adapted species, they should love high (=sea water) salinity and avoid low salinity, that probably why many crab species could be attracted in this zone.

Some crab species show a preferential distribution in the particular mangrove plants perhaps for feeding behavior or for a suitable refuge. A. elegans, C. armatum, C. buetikoferi and P. huzardi were found in G. demeusei, $P$. candelabrum, H. tiliaceus and C. mannii zones respectively. In Malaysia, Sesarma onychoponum and S. Eumolpe distribution in the field was related to the preferred for Bruguiera and Rhizophora tree species dominance, indicating that tree species may be important for crab species distribution, or vice versa [39]. On the other hand, $P$. kamermani, $P$. transversus and $C$. angolense have shown ubiquitous behaviors. It has therefore become difficult to determine which plant directly influences their distribution. At this time, other factors such as the properties of habitats like roots or pneumatophorous, salinity and granulometry can affect their distribution [58].

Sesarmid crabs are the most abundant (85\%) with high number of species (eight) in the Wouri Estuary mangroves. These species are recognizing to prefer the leaves and young Rhizophora propagules [26] [42] [59]. It is apparent there is a mutual relationship between sesarmid crabs and mangroves, whereby mangroves provide a suitable habitat and the crabs reduces competition between mangrove plant species through selective predation on seedlings [25] [60].

\subsubsection{Influence of Soil Water Characteristics}

Salinity is considered as an ecological key factor in estuarine and coastal zones that are characterized by a high 
variability. Variation of salinity observed in transects is due to the penetration of water during high tides followed by evaporation and increase of ground water capillarity during low tides. This mechanism would contribute to the retention of a large quantity of salt in the mangrove [61]. The values of salinity of Wouri mangroves are relatively weak $2 \%$ - $10 \%$ compared to those obtained in the mangroves of Kenya: $16 \%$ - 65\% [62] and those of Mayotte: 37\% - 72\%o [52]. These values of salinity obtained in the rainy season are certainly higher in the dry season.

The crab species do not have the same capacities of osmoregulation and their physiological answers with respect to various salinities are different [63]. The high salinity zones $\left(8-9 \mathrm{~g} \cdot \mathrm{l}^{-1}\right)$ have been dominated by $P$. transversus, $P$. validus and C. angolense corresponding to Avicennia germinans (L.) Stearn, C. mannii and $L$. racemosa zones. C. armatum was found only in the low salinity zones $\left(\leq 2.4 \mathrm{~g} \cdot l^{-1}\right)$ dominated by $P$. candelabrum zone. C. buetikoferi, Sesarma sp. and U. tangeri tolerate medium level of salinity which corresponds to Rhizophora spp., G. demeusei, $H$. tiliaceus and $N$. fruticans zones. It's still difficult to relate crab distribution to salinity instead of vegetation properties.

$U$. tangeri was only found in the high temperature zones. The temperatures of $24^{\circ} \mathrm{C}$ to $29^{\circ} \mathrm{C}$ are optimum surface temperature to stimulate emergence of Uca species from burrows [64]. The $\mathrm{pH}$ of ground water was correlated with the crab community structure. Most species were encountered in Rhizophora spp. zones which have the high $\mathrm{pH}$ values. Low-pH conditions can be detrimental to crabs because they depend on calcium carbonate formation for exoskeleton and shell building respectively.

\subsubsection{Influence of Channel Distance}

All mangrove crabs have some degree of behavioral, morphological, physiological and biochemical adaptation to their habitat. $P$. transversus, $P$. validus and $C$. angolense have been found near channels. P. validus (Portunid crab) is a swimming crab, probably that's the reason why it was found near the channel. Only Ocypodid crab (Uca perplexa) was studying near water by [65]. To adapt, this species usually loses water at a high respiration rate and they supplement the water level lost by lowering the body temperature. This is probably the same thing for the grapsid and sesarmid crabs.

C. armatum and $U$. tangeri appeared as the most terrestrial crabs of mangroves environment. The first lives essentially close to mangroves in particular at the back of mangroves because of reproduction cycle and can breathe in the presence of moist air [66]. It stores up nitrogenous waste until water becomes available by reducing gills number and space and increases his epithelial fabric. The second has the smaller hearing compared with others species of the moist habitats [65].

These two semi-terrestrial crabs are capable to carry out osmoregulation to adapt [66]. Their keystone effects are a consequence of their feeding habits and burrowing behavior [60]. The burrows and tunnels build by the land crabs (Sesarma, Cardisoma and Uca species) provide them protection against high temperatures, low humidity, wind and predators [67] [68].

\section{Conclusion}

The macrofauna structure is postulated to be functionally related to the environmental factors. This survey has shown relationships between crabs and vegetation. There's also a crab zonation along salinity, $\mathrm{pH}$ and temperature gradient of ground water. Rhizophora zone appeared to be the most attracting both in quality and quantity. Crab zonation is often greatly complicated in the context of permanently mangrove fluctuations. It's still necessary to reveal clearly the main parameter which affected crabs distribution. The sampling design and correlations between key factors are also involved complex analysis.

\section{References}

[1] Kristensen, E. (2008) Mangrove Crabs as Ecosystem Engineers; with Emphasis on Sediment Processes. Journal of Sea Research, 59, 30-43. http://dx.doi.org/10.1016/j.seares.2007.05.004

[2] Warner, G.F. (1969) The Occurrence and Distribution of Crabs in a Jamaican Mangrove Swamp. Journal of Animal Ecology, 38, 379-389. http://dx.doi.org/10.2307/2777

[3] Din, N. and Baltzer, F. (2008) Richesse Floristique et Evolution des mangroves de l’Estuaire du Cameroun. African Geosciences Review, 2, 119-130.

[4] Din, N., Priso, R.J., Kenne, M., Ngollo, D.E. and Blasco, F. (2002) Early Growth Stages and Natural Regeneration of 
Avicennnia germinans (L.) Stearn in the Wouri Estuarine Mangroves (Douala-Cameroun). Wetlands Ecology and Management, 10, 461-467. http://dx.doi.org/10.1023/A:1021351707822

[5] Lee, S.Y. (1998) Ecological Role of Grapsid Crabs in Mangrove Ecosystems: A Review. Marine and Freshwater Research, 49, 335-343. http://dx.doi.org/10.1071/MF97179

[6] Lee, S.Y. (2008) Mangrove Macrobenthos: Assemblages, Services, and Linkages. Journal of Sea, 59, 16-29. http://dx.doi.org/10.1016/j.seares.2007.05.002

[7] Nagelkerken, I., Kirton, L.G., Meynecke, J.O., Pawlik, J., Penrose, H.M., Blaber, S.J.M., Bouillon, S., Green, P., Haywood, M., Sasekumar, A. and Somerfield, P.J. (2008) The Habitat Function of Mangroves for Terrestrial and Marine Fauna: A Review. Aquatic Botany, 89, 155-185. http://dx.doi.org/10.1016/j.aquabot.2007.12.007

[8] Paula, J., Dornelas, M. and Flores, A.A.V. (2003) Stratified Settlement and Moulting Competency of Brachyuran Megalopae in Ponta Rasa Mangrove Swamp, Inhaca Island (Mozambique). Estuarine and Coastal Shelf Science, 56, 325-337. http://dx.doi.org/10.1016/S0272-7714(02)00165-8

[9] Diaz, R.J., Solan, M. and Valente, R.M. (2004) A Review of Approaches for Classifying Benthic Habitats and Evaluating Habitat Quality. Journal of Environmental Management, 73, 165-181. http://dx.doi.org/10.1016/j.jenvman.2004.06.004

[10] Neves, R.A.F., Echeverria, C.A., Pessoa, I.A., Paiva, P.C., Paranhos, R. andValentine, J.I. (2012) Factors Influencing Spatial Patterns of Molluscs in a Eutrophic Tropical Bay. Journal of the Marine Biological Association of the United Kingdom, 10, 1-13.

[11] Esenowo, I.K. and Ugwumba, A.A.A. (2010) Composition and Abundance of Macrobenthos in Majidun River, Ikorordu Lagos State, Nigeria. Research Journal of Biological Sciences, 5, 556-560. http://dx.doi.org/10.3923/rjbsci.2010.556.560

[12] Rakotomavo, A. and Fromard, F. (2010) Dynamics of Mangrove Forests in the Mangoky River Delta, Madagascar, under the Influence of Natural and Human Factors. Forest Ecology and Management, 259, 1161-1169. http://dx.doi.org/10.1016/j.foreco.2010.01.002

[13] Spalding, M., Blasco, F. and Field, C. (1997) World Mangrove Atlas. International Society for Mangrove Ecosystems, Okinawa.

[14] Spalding, M., Kainuma, M. and Collins, L. (2010) World Atlas of Mangroves. The International Society for Mangrove Ecosystems, Okinawa.

[15] Ellison, J.C. and Zouh, I. (2012) Vulnerability to Climate Change of Mangroves: Assessment from Cameroon, Central Africa. Biology, 1, 617-638. http://dx.doi.org/10.3390/biology1030617

[16] Nfotabong, A.A., Din, N. and Dahdouh-Guebas, F. (2013) Qualitative and Quantitative Characterization of Mangrove Vegetation Structure and Dynamics in a Peri-urban Setting of Douala (Cameroon): An Approach Using Air-Borne Imagery”, Estuaries and Coasts, 36, 1181-1192. http://dx.doi.org/10.1007/s12237-013-9638-8

[17] Nfotabong, A.A. (2011) Impact of Anthropogenic Activities on the Vegetation Structure of Mangrove Forests in Kribi, the Nyong River Mouth and Cameroon Estuary. Ph.D. thesis, Université Libre de Bruxelles-ULB, Belgium/The University of Douala, Cameroon.

[18] Walters, B.B., Rönnbäck, P., Kovacs, J.M., Crona, B., Hussain, S.A., Badola, R., Primavera, J.H., Barbier, E. and Dahdouh-Guebas, F. (2008) Ethnobiology, Socio-Economics and Management of Mangrove Forests: A Review. Aquatic Botany, 89, 220-236. http://dx.doi.org/10.1016/j.aquabot.2008.02.009

[19] Cannicci, S., Bartolini, F., Dahdouh-Guebas, F., Fratini, S., Litulo, C., Macia, A., Elisha Mrabu, J., Penha-Lopes, G. and Jose, P. (2009) Effects of Urban Waste Water on Crab and Subtropical Mangroves of East Africa. Estuarine Coastal and Shelf Science, 30, 1-14.

[20] Dahdouh-Guebas, F., Van Pottelbergh, I., Kairo, J.G., Cannicci, S. and Koedam, N. (2004) Human-Impacted Mangroves in Gazi (Kenya): Predicting Future Vegetation Based on Retrospective Remote Sensing, Social Surveys, and Distribution of Trees. Marine Ecology Progress Series, 272, 77-92. http://dx.doi.org/10.3354/meps272077

[21] Hartnoll, R.G., Cannicci, S., Emmerson, W.D., Fratini, S., Macia, A., Mgaya, Y., Porri, F., Ruwa, R.K., Shunnula, J.P., Skov, M.W. and Vannini, M. (2002) Geographic Trends in Mangrove Crab Abundance in East Africa. Wetlands Ecology and Management, 10, 203-213. http://dx.doi.org/10.1023/A:1020123713133

[22] Pape, E., Muthumbi, A., Kamanu, C.P. and Vanreusel, A. (2008) Size-Dependent Distribution and Feeding Habits of Terebralia palustris in Mangrove Habitats of Gazi Bay, Kenya. Estuarine Coastal and Shelf Science, 76, 797-808. http://dx.doi.org/10.1016/j.ecss.2007.08.007

[23] Vannini, M., Lori, E., Coffa, C. and Fratini, S. (2008) Cerithidea decollata: A Snail That Can Foresee the Future? Animal Behaviour, 76, 983-992.

Vannini, M., Coffa, C., Lori, E. and Fratini, S. (2008) Vertical Migrations of the Mangrove Snail Cerithidea decollata (L.) (Potamididae) through a Synodic Month. Estuarine Coastal and Shelf Science, 78, 644-648. 
http://dx.doi.org/10.1016/j.ecss.2008.02.010

[24] Dahdouh-Guebas, F., Koedam, N., Satyanarayana, B. and Cannicci, S. (2011) Human Hydrographical Changes Interact with Propagule Predation Behaviour in Sri Lankan Mangrove Forests. Journal of Experimental Marine Biology and Ecology, 399, 188-200. http://dx.doi.org/10.1016/j.jembe.2010.11.012

[25] Bosire, J.O., Kairo, J.G., Kazungu, J., Koedam, N. and Dahdouh-Guebas, F. (2005) Predation on Propagules Regulates Regeneration in a High-Density Reforested Mangrove Plantation. Marine Ecology Progress Series, 299, 149-155. http://dx.doi.org/10.3354/meps299149

[26] Cannicci, S., Burrows, D., Fratini, S., Lee, S.Y., Smith III, T.J., Offenberg, J. and Dahdouh Guebas, F. (2008) Faunistic Impact on Vegetation Structure and Ecosystem Function in Mangrove Forests: A Review. Aquatic Botany, 89, 186-200. http://dx.doi.org/10.1016/j.aquabot.2008.01.009

[27] Cannicci, S., Fratini, S. and Vannini, M. (1999) Short Range Homing in Fiddler Crabs (Ocypodidae, Genus Uca): A Homing Mechanism Not Based on Local Visual Landmarks. Ethology, 105, 867-880. http://dx.doi.org/10.1046/j.1439-0310.1999.00453.x

[28] Vannini, M., Rorandelli, R., Lahteenoja, O., Mrabu, E. and Fratini, S. (2006) Tree-Climbing Behaviour of Cerithidea decollata, a Western Indian Ocean Mangrove Gastropod (Mollusca: Potamididae). Journal of the Marine Biological Association of the United Kingdom, 86, 1429-1436. http://dx.doi.org/10.1017/S0025315406014470

[29] Skov, M.W. and Hartnoll, R.G. (2002) Paradoxical Selective Feeding on a Low-Nutrient Diet: Why Do Mangrove Crabs Eat Leaves? Oecologia, 131, 1-7. http://dx.doi.org/10.1007/s00442-001-0847-7

[30] Cannicci, S., Barelli, C. and Vanninni, M. (2000) Homing in the Swimming Crab Thalamita crenata: A Mechanism Based on Underwater Landmark Memory. Animal Behaviour, 60, 203-210. http://dx.doi.org/10.1006/anbe.2000.1458

[31] Twilley, R.R., Pozo, M., Garcia, V.H., Rivera-Mouray, V.H., Zambrano, R. and Bodero, A. (1997) Litter Dynamics in Riverine Mangrove Forests in the Guayas River Estuary, Ecuador. Oecologia, 111, 109-122. http://dx.doi.org/10.1007/s004420050214

[32] Ngo-Massou, V.M., Essomè-Koum, G.L., Ngollo-Dina, E. and Din, N. (2012) Composition of Macrobenthos in the Wouri River Estuary Mangrove, Douala, Cameroon. African Journal of Marine Science, 34, 349-360. http://dx.doi.org/10.2989/1814232X.2012.725288

[33] Ysebaert, T., Herman, P., Meire, P., Craeymeersch, J., Verbeek, H. and Heip, C. (2003) Large-Scale Spatial Patterns in Estuaries: Estuarine Macrobenthic Communities in the Schelde Estuary, NW Europe. Estuarine, Coastal and Shelf Science, 57, 335-355. http://dx.doi.org/10.1016/S0272-7714(02)00359-1

[34] Anderson, M., Ford, R., Feary, D. and Honeywill, C. (2004) Quantitative Measures of Sedimentation in an Estuarine System and Its Relationship with Intertidal Soft-Sediment Infauna. Marine Ecology Progress Series, 272, 33-48. http://dx.doi.org/10.3354/meps272033

[35] Wolcott, T. (1988) Ecology. In: Burggren, W.W. and McMahon, B.R., Eds., Biology of Land Crabs, Cambridge University Press, Cambridge, 55-96. http://dx.doi.org/10.1017/CBO9780511753428.004

[36] Rodriguez-Fourquet, C. and Sabat, A.M. (2009) Effect of Harvesting, Vegetation Structure and Composition on the Abundance and Demography of the Land Crab Cardisoma guanhumi in Puerto Rico. Wetlands Ecology and Management, 17, 627-640. http://dx.doi.org/10.1007/s11273-009-9139-5

[37] Sherman, P. (2003) Effects of Land Crabs on Leaf Litter Distributions and Accumulations in a Mainland Tropical Rain Forest. Biotropica, 35, 365-374.

[38] Pedersen, C., Everett, B. and Fielding, P. (2003) Subsistence Utilization of the Crab Neosarmatium meinerti in the Kosi Lakes Ecosystem, KwaZulu-Natal, South Africa. African Zoology, 38, 15-28.

[39] Ashton, E.C. (2002) Mangrove Sesarmid Crab Feeding Experiments in Peninsular Malaysia. Journal of Experimental Marine Biology and Ecology, 273, 97-119. http://dx.doi.org/10.1016/S0022-0981(02)00140-5

[40] Erickson, A.A., Saltis, M., Bell, S.S. and Dawes, C.J. (2003) Herbivore Feeding Preferences as Measured by Leaf Damage and Stomatal Ingestion: A Mangrove Crab Example. Journal of Experimental Marine Biology and Ecology, 289, 123-138. http://dx.doi.org/10.1016/S0022-0981(03)00039-X

[41] Ondo Assoumou, E. (2006) Dynamique des paysages végétaux du Littoral Centre-Ouest du Gabon autour de Port-Gentil: Approche spatial et Analyse des Données du terrain. Thèse de Doctorat, Université Paul Valéry Montpellier, Montpellier, 302.

[42] Ashton, E.C., Hogarth, P.J. and Macintosh, D.J. (2003) A Baseline Study of the Diversity and Community Ecology of Crab and Molluscan Macrofauna in the Semantan Mangrove Forest, Sarawak, Malaysia. Journal of Tropical Ecology, 19, 127-142. http://dx.doi.org/10.1017/S0266467403003158

[43] Vazzoler, A.E.A.M. (1996) Biologia da Reprodução de Peixes Teleòsteos: Teoria e Pràtica. Universidade Estadual de Maringà, EDUEM, Sao Paulo, 169 p. 
[44] Sokal, R.R. and Rohlf, J. (1987) Introduction to Biostatistics. 2nd Edition, Freeman and Company, New York, 363.

[45] Koga, T., Backwell, P.R., Christy, J.H., Murai, M. and Kasuya, E. (2001) Male-Biased Predation of a Fiddler Crab. Animal Behaviour, 62, 201-207. http://dx.doi.org/10.1006/anbe.2001.1740

[46] Macia, A., Quincardete, I. and Paula, J. (2001) A Comparison of Alternative Methods for Estimating Population Density of the Fiddler Crab Uca annulipes at Saco Mangrove, Inhaca Island (Mozambique). Hydrobiologia, 449, 213-219. http://dx.doi.org/10.1023/A:1017502817087

[47] Longonje, S. (2008) Distribution, Diversity and Abundance of Crabs in Cameroon Mangroves. PhD Thesis, University of York, York.

[48] Johnson, P.T.J. (2003) Biased Sex Ratios in Fiddler Crabs (Brachyura, Ocypodidae): A Review and Evaluation of the Influence of Sampling Method, Size Class and Sex-Specific Mortality. Crustaceana, 76, 559-580. http://dx.doi.org/10.1163/156854003322316209

[49] Emmerson, W.D. (1994) Seasonal Breeding Cycles and Sex Ratios of Eight Species of Crabs from Mgazana, a Mangrove Estuary Transkei. South African Journal of Crustacean Biology, 14, 158-163.

[50] Costa, T.M. and Negreiros-Fransozo, M.L. (2003) Population Biology of Uca thayeri Rathbun, 1900 (Brachyura, Ocypodidae) in a Subtropical South America Mangrove Area: Result from Transect and Catch Per-Unit Effort Technique. Crustaceana, 75, 1201-1218. http://dx.doi.org/10.1163/156854002321518144

[51] Litulo, C. (2005) Population Structure and Reproduction Biology of the Fiddler Crab Uca inversa (Hoffman, 1874) (Brachyura: Ocypodidae). Acta Oecologica, 27, 135-141. http://dx.doi.org/10.1016/j.actao.2004.11.002

[52] Herteman, M. (2010) Evaluation des capacités bioremédiatrices d'une mangrove impactée par des eaux usées domestiques: Application au site pilote de Malamani, Mayotte. Doctorat de l’Université de Toulouse, Toulouse, 330.

[53] Castiglioni, D.S., Negreiros-Fransozo, M.L. and Mortari, R.C. (2006) Biologia Populacional Do Caranguejo Violinista Uca Rapax (Smith, 1870) (Crustacea, Ocypodoidea), Proveniente De Uma Área De Manguezal Degradado Em Paraty, Rj, Brasil. Atlântica Rio Grande, 28, 73-86.

[54] Fransozo, V., Mortari, R.C. and Benetti, A.S. (2009) Biologia Populacional de Uca mordax (Smith 1870) (Crustacea, Decapoda, Ocypodidae) do litoral sudeste do Brasil. Estudos de Biologia, 31, 23-31.

[55] Cumberlidge, N. (2006) Rapid Survey of the Decapods Crustaceans of the Boké Prefecture Guinea. In: Rapid Biological Assessment of Boké Préfecture, Northwestern Guinea, RAP Bulletin of Biological Assessment 41, Distributed for Conservation International, 192.

[56] Wang, Y.D., Xiong, B.X., Chen, C.B. and Hu, H.S. (2005) The Effect of Environment Factors on Life Activity of Zoobenthos. Journal of Zhejiang Ocean University (Natural Science), 3, 253-257.

[57] Zhou, X., Cai, L., Fu, S. and Wang, W. (2010) Comparative Study of the Macrobenthic Community in Intertidal Mangrove and Non-Mangrove Habitats in Tong'an Bay, Fujian Province. Biodiversity Science, 18, 60-66.

[58] Skilleter, G.A. and Warren, S. (2000) Effects of Habitat Modification in Mangroves on the Structure of Mollusc and Crab Assemblages. Journal of Experimental Marine Biology and Ecology, 244, 107-129. http://dx.doi.org/10.1016/S0022-0981(99)00133-1

[59] Dahdouh-Guebas, F., Koedam, N., Satyanarayana, B. and Cannicci, S. (2010) Human Hydrographical Changes Interact with Propagule Predation Behaviour in Sri Lankan Mangrove Forests. Journal of Experimental Marine Biology and Ecology, 399, 188-200. http://dx.doi.org/10.1016/j.jembe.2010.11.012

[60] Green, P.T., O’dowd, D.J. and Lake, P.S. (2008) Recrutment Dynamics in a Rainforest Seedling Community: ContextIndependent Impact of a Keystone Consumer. Oecologia, 156, 373-385.

[61] Tam, N.F.Y. and Wong, Y.S. (1998) Variation of Soil Nutrient and Organic Matter Content in a Subtropical Mangrove Ecosystem. Water, Air, Soil and Pollution, 103, 245-261. http://dx.doi.org/10.1023/A:1004925700931

[62] Gillikin, D.P., De Wachter, B. and Tack, J.F. (2004) Physiological Responses of Two Ecologically Important Kenyan Mangrove Crabs Exposed to Altered Salinity Regimes. Journal of Experimental Marine Biology and Ecology, 301, 93109. http://dx.doi.org/10.1016/j.jembe.2003.09.024

[63] Nobbs, M. (2003) Effect of Vegetation Differs among Three Species of Fiddler Crabs (Uca spp.). Journal of Experimental Marine Biology and Ecology, 284, 41-50. http://dx.doi.org/10.1016/S0022-0981(02)00488-4

[64] Lim, S.S.L. and Wong, J.A.C. (2010) Burrow Residency and Re-Emergence Rate in a Droving Species, Uca vocans (Linnaeus, 1758) and Its Sympatric Associate, U. annulipes (H. Milne Edwards, 1837) (Brachyura, Ocypodidae). Crustaceana, 83, 677-693. http://dx.doi.org/10.1163/001121610X492157

[65] Takeda, S. (2003) Mass Wandering in the Reproductive Season by the Fiddler Crab Uca perplexa (Decapoda: Ocypodidae). Journal of Crustacean Biology, 23, 723-728. http://dx.doi.org/10.1651/C-2352

[66] Guiral, D., Albaret, J.J., Baran, E., Bertrand, F., Debenay, J.P., Diouf, P.S., Guillou, J.J., Le Loeuff, P., Montoroi, J.P. and Sow, M. (1999) Rivières du Sud: Sociétés et Mangroves Ouest-africaines. IRD, Paris, 23-36. 
[67] Bliss, D. (1979) From Sea to Tree: Saga of a Land Crab. American Zoologist, 19, 385-410.

[68] Greenaway, P. (1988) Ion and Water Balance. In: Burggren, W.W. and McMahon, B.R., Eds., The Biology of Land Crabs, Cambridge University Press, Cambridge, 211-248. http://dx.doi.org/10.1017/CBO9780511753428.008 